\title{
Above Carbon Stoks Potential in Universitas Negeri Semarang
}

\author{
Moch. Samsul Arifin ${ }^{1, *}$ \\ ${ }^{1}$ Master Program of Environmental Science, School of Postgraduate Studies, Diponegoro University, Semarang - Indonesia
}

\begin{abstract}
The rapid development of campus physical facilities has caused a decrease in green open space at the Universitas Negeri Semarang (Unnes). Vegetation plays a role in absorbing and storing $\mathrm{CO}_{2}$, so that reduced green open space can reduce carbon stocks and contribute to increasing atmospheric $\mathrm{CO} 2$ emissions. Regarding on this matter, program sinks through $\mathrm{CO}_{2}$ uptake by vegetation need to be considered as an effort to reduce $\mathrm{CO}_{2}$ emissions. Information about the carbon stocks is required to support the program sink. The purpose of this study was to estimate the amount of above carbon stocks in Unnes. Tree carbon stocks are estimated through allometric equations and field measurements of several parameters such as diameter, height, number and species of trees. Carbon stocks in understorey, litter and necromass are estimated by measuring the dry weight. The results showed that above carbon stocks in Unnes were 289,92 Ton $\mathrm{Mg} / \mathrm{ha}$, or $6.188,57 \mathrm{Mg}$.
\end{abstract}

Keywords: carbon stok; green open space; universitas negeri semarang.

\section{Introduction}

Universitas Negeri semarang (Unnes) is one of the universities in Indonesia that applies the "eco-friendly" principle in its campus governance. The spirit of "ecofriendliness" was confirmed by Unnes through its declaration as a conservation university on March 12 , 2010. The vision of Unnes as a conservation university was realized through activity programs including tree planting movements which were attended by all Unnes academician. The planting movement has even been implemented before the declaration and has been regulated through the Unnes Rector's Regulation No.26 th. 2009 About Planting Movement One Tree one Student [1]. The planting movement makes the Unnes campus area very green because it has a lot of green open spaces that are overgrown by tree stands. Setting Campus arrangement with many tree stands and vegetation cover has led Unnes to become one of the greenest universities both at national and international levels [2].

Unnes has developed campus physical facilities quite rapidly in recent years, and has been planned in the Unnes master plan review until 2025. The development of campus physical facilities such as office buildings, lecture buildings and services, as well as other supporting infrastructure is intended to meet the needs of students whose increase every years. It potentially reduces the extent of green open space and has implications for reduced absorption and loss of carbon deposits. Carbon originally deposited in trees will be released into the atmosphere through a decomposition process at the time of land clearing [3]. Conversion of green areas also causes an increase in air temperature and drought [4].

The Low Emission Development (LED) Strategy is an alternative strategy that needs to be considered in campus development [5]. LED strategies can be applied through sink programs by utilizing the ability of carbon uptake by vegetation. The sink program can be one of the most implementable ways to mitigate global warming and climate change [6]. Information about above carbon stocks is essential in supporting Low Emission Development in Unnes. Information about above carbon stocks can be obtained by measuring biomass in vegetation, because biomass can be used to describe the carbon contain in vegetation [7].

This research study was aimed to estimate the amount of above carbon stocks in Unnes.

\section{Methodology}

The research was conducted from February until April 2018 in Sekaran Campus Unnes, Semarang City, Central Jawa, Indonesia (Fig. 1).

* Corresponding author: arif_rrf@yahoo.com 


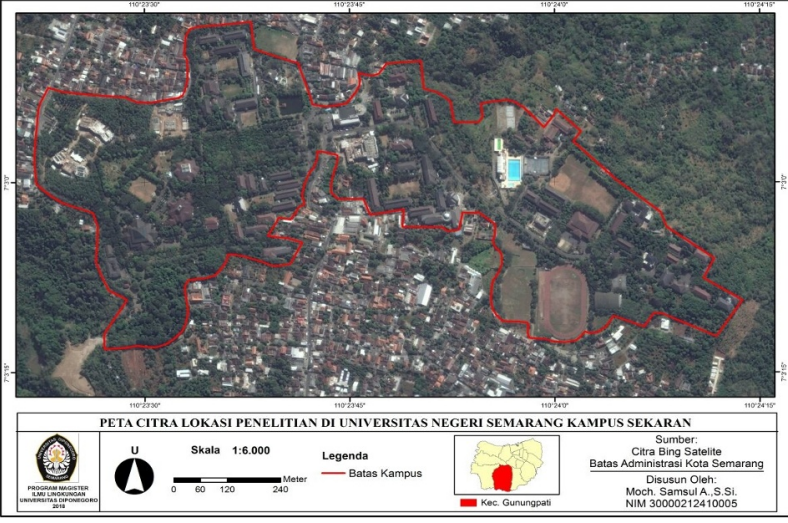

Fig. 1. Site of Universitas Negeri Semarang

Measurement of tree biomass was done without harvesting or 'non destructive' by estimating tree volume. The parameters measured were stem diameter at breast height (1.3 $\mathrm{m}$ above ground level), number and species of trees. If necessary then the height of the tree can also be measured to enhance the accuracy of the estimated volume of the tree. Tree biomass was calculated using allometric equations according to [7] and [8] (Table 1). Determination of wood density was done using a table of gravity types expressed by ICRAF (International Center for Research on Agroforestry).

Table 1. Lists of allometric equation used to estimate tree biomass content.

\begin{tabular}{|l|l|l|}
\hline No & \multicolumn{1}{|c|}{ Tree Type } & \multicolumn{1}{|c|}{ Allometric equation } \\
\hline 1 & Tree are not branched & $\mathrm{Y}=\pi \rho \mathrm{H} \mathrm{D}^{2} / 40$ \\
\hline 2 & Branched tree & $\mathrm{Y}=0.11 \rho \mathrm{D}^{2.62}$ \\
\hline 3 & Banana tree & $\mathrm{Y}=0.030 \mathrm{D}^{2.13}$ \\
\hline 4 & Sengon tree & $\mathrm{Y}=0.0272 \mathrm{D}^{2.831}$ \\
\hline 5 & Bamboo & $\mathrm{Y}=0.131 \mathrm{D}^{2.28}$ \\
\hline 6 & Pine tree & $\mathrm{Y}=0.0417 \mathrm{D}^{2.6576}$ \\
\hline
\end{tabular}

The carbon analysis in Unnes used the biomass content approach developed by [9]. The general formulation used is:

$$
C=0.46 \times W
$$

Description: C: Carbon Reserves $(\mathrm{MgC}), \mathrm{W}$ : Biomass $(\mathrm{kg}), 0.46$ : Coefficient of carbon content in plants.

The analysis of land cover used in this research is the NDVI (Normalized Difference Vegetation Index). The value of NDVI shows the vegetation density level based on the greenishness of vegetation.

$$
\mathrm{NDVI}=\frac{\mathrm{NIR}-\mathrm{RED}}{\mathrm{NIR}+\mathrm{RED}}
$$

Description: NIR = Infrared Band Value; Red $=$ Red Band Value.

NDVI values are in the range between -1 to 1 . The values of -1 to 0 indicate that the area has no vegetation cover. The classification of Unnes land images is based on the value of the vegetation index (NDVI). The vegetation index value of each transformation was explained for the determination of vegetation density, ie, rare density level $(0.10 \leq \mathrm{NDVI} \leq 0.15)$, medium $(0.160$ $\leq \mathrm{NDVI} \leq 0.20)$, height $(>0.21)[10]$.

The regression model used in this study:

$$
\hat{y}=a+b x
$$

Description: $y=$ Dependent variable; $a$ and $b=$ constants, while $x=$ Independent variable. In this study, the independent variable is the NDVI value, while the carbon stock is the dependent variable.

\section{Result}

Unnes Sekaran campus is astronomically located between $110^{\circ} 23^{\prime} 49,4^{\prime \prime} \mathrm{S}$ and $07^{\circ} 02^{\prime} 59,3^{\prime \prime}$ E. Administratively the Sekaran campus Unnes is located in Sekaran village, Gunungpati District, Semarang City, Central Java, Indonesia. Unnes Sekaran Campus stands on an area of 65,28 ha, and consists of 8 faculties. The Unnes Sekaran campus location is limited by:

- North: bordering the Hamlet of Banaran, Sekaran Village.

- East: bordering the Hamlet of Banaran, Sekaran Village.

- To the south: bordering the Hamlet of Sekaran, Sekaran Village.

- West: bordering the Hamlet of Bandardowo, Sekaran Village.

Unnes Sekaran campus located in the hills with an altitude of approximately $200 \mathrm{~m}$ above sea level which turned out to create a visual value of beautiful scenery. The view of Mount Ungaran can be seen intact to the south at a fairly open view. The magnificent view of Semarang city lights can be seen intact to the north at night.

Unnes Sekaran Campus includes areas that have a wet climate with rainfall of 3,300-3,400 mm/year [11]. Type of land on Unnes sekaran campus same as the type of land in general in Sekaran Village. The BPN data states that based on the analysis of the Semi Detailed Land Resources Map Scale of 1: 50,000 shows that Sekaran village has two types of soil namely brown latosol and dark brown latosol. The dark brown Latosol complex has an area of 58.07 ha or $10 \%$ of the total area of Sekaran Village, while the brown latosol complex has an area of 522,66 ha or $90 \%$ of the total area of Sekaran Village[12].

\subsection{Normalized Difference Vegetation Index (NDVI)}

Interpretation of Landsat 8 Satellite Imagery shows that the value of NDVI is in the range 0.0258 to 0.7906 with the vegetation threshold value at 0.318 . The vegetation index below the threshold value is known as non vegetated land. The density of vegetation based on 
NDVI values can be used as the basis for classifiying according to the dominance of plants [13]. Based on NDVI values and field data samples, the vegetation density in Unnes can be classified into three classes, namely high, medium and low density (Table 2).

Tabel 2. NDVI values based on vegetation density at Unnes

\begin{tabular}{|l|l|c|c|l|}
\hline No & $\begin{array}{c}\text { Class of } \\
\text { Vegetation }\end{array}$ & NVDI & $\begin{array}{c}\% \\
\text { vegetation }\end{array}$ & information \\
\hline 1 & Low & $\begin{array}{l}0.3180- \\
0.5006\end{array}$ & $24,85 \%$ & Grases \\
\hline 2 & Medium & $\begin{array}{l}0.5158- \\
0.6086\end{array}$ & $25,13 \%$ & Shrubs \\
\hline 3 & High & $0.6116-$ & $50,02 \%$ & Trees \\
& & 0.7906 & & \\
\hline \multicolumn{2}{|l|}{ Total } & $100 \%$ & \\
\hline
\end{tabular}

Table 2 shows the low vegetation density classes mostly in the form of grass / garden / field contained in the $0.3180-0.5006$ range of $24.85 \%$ of the total vegetation area or 12.66 ha $(21.06 \%$ of Unnes area). Medium vegetation density classes are mostly grass, shrubs and trees at low density poles and piles ranging from $0.5158-0.6086$ area of $25.13 \%$ of total vegetation area or 12.81 ha $(21.31 \%$ widespread Unnes). High vegetation density classes consist of tree stands in the range of $0.6116-0.7906$ covering $50.02 \%$ of the total vegetation area or 25.49 ha $(42.39 \%$ of Unnes area). Thus, the total area of vegetation cover in Unnes is 50.96 ha or $84.76 \%$ of the total land area of Unnes.

Images obtained from a combination of Landsat 8 and NDVI Satellite Imagery can be seen on the map (Fig. 2) that the orange to blue color is vegetation. The closer the blue and the darker the blue color indicates the higher the vegetation density. Reddish color indicates the land is not vegetated, open land or waking land.

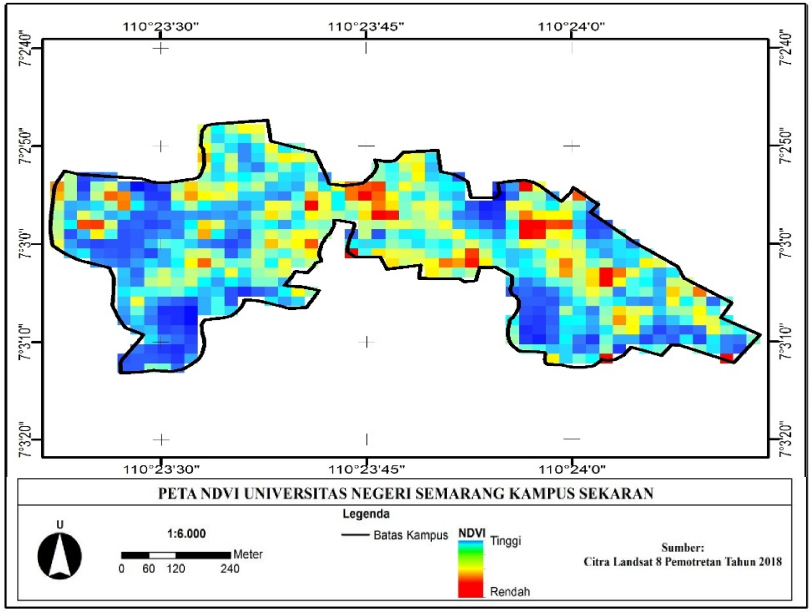

Fig. 2. The NDVI distribution in Universitas Negeri Semarang

\subsection{Estimation of Biomass and Above Carbon Stock Potential in Unnes}

Tree biomass and woody necromasses are estimated using allometric equations that have been developed by previous researchers. The parameters required in this allometric equation are height, diameter at breast height and information on wood density of species to support accuracy in calculating biomass. The wood density of species used to estimate the biomass in this study was obtained from a database developed by ICRAF (International Center for Research in Agroforestry).

The understorey and litter biomass obtained from the dry weight of the sub-sample divided by the weight of the sub-sample then multiplied by the total value of the wet weight present in the measuring plot $(0.5 \times 0.5$ $\mathrm{m})$. The obtained biomass yield is still in units of gram per unit area, so it needs to be converted into $\mathrm{Mg} / \mathrm{ha}$. The content of vegetation biomass at tree, pole and stake, woody necromassa, under storey and litter in the three classes of vegetation cover is presented in Fig. 3 .

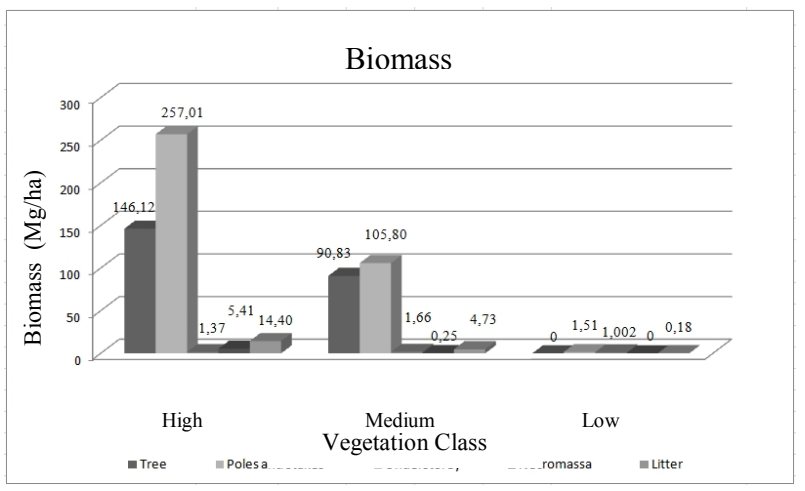

Fig. 3. Biomass content in various vegetation classes

Figure 3 shows that the total biomass content contained in vegetation in the three classes of vegetation density is $630,27 \mathrm{Mg} / \mathrm{ha}$. It consists of vegetation stand biomass at the tree level of $236,95 \mathrm{Mg} / \mathrm{ha}$, poles and sapling rates of $364,32 \mathrm{Mg} / \mathrm{ha}$, understorey of 4,04 $\mathrm{Mg} / \mathrm{ha}$, woody necromassa of $5,66 \mathrm{Mg} / \mathrm{ha}$ and litter of $19,30 \mathrm{Mg} / \mathrm{ha}$. The highest biomass content was found in the high vegetation density class with total biomass of $424,3 \mathrm{Mg} / \mathrm{ha}$, followed by the medium vegetation density class of $203,27 \mathrm{Mg} / \mathrm{ha}$ and the lowest biomass content was found in the low vegetation density class of $2,7 \mathrm{Mg} / \mathrm{ha}$.

The carbon concentration contained in organic matter is estimated to be $46 \%$ of the biomass [7]. Then the estimated carbon stock can be calculated by multiplying the total of biomass with the carbon concentration, according to the equation $\mathrm{C}=0.46 \mathrm{x} \mathrm{W}$. The calculation of carbon stocks on the various classes of vegetation in Unnes is presented in Fig. 4.

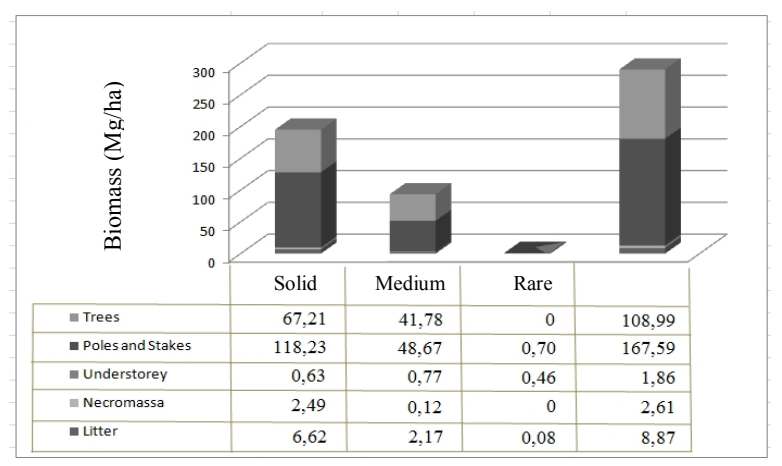

Fig. 4. Carbon stocks in various vegetation classes 
Figure 4 shows that on every hectare of green open space Unnes stored carbon reserves of $289,93 \mathrm{Mg} / \mathrm{ha}$. The high vegetation density class has the highest carbon stock of $195,18 \mathrm{Mg} / \mathrm{ha}$, followed by the medium vegetation density class grade of $93,51 \mathrm{Mg} / \mathrm{ha}$ and the low vegetation density class has the smallest carbon stock of $1,24 \mathrm{Mg} / \mathrm{ha}$. Carbon stocks found in pile and stake vegetation are the highest than carbon stocks at other vegetation levels. Carbon stocks in pile and stake vegetation are $167,59 \mathrm{Mg} /$ ha, tree level of $108,99 \mathrm{Mg} / \mathrm{ha}$, litters of $8,87 \mathrm{Mg} / \mathrm{ha}$, woody necromassa of 2,61 Mg/ha, while the smallest carbon reserves are in the understorey that is equal to $1,86 \mathrm{Mg} / \mathrm{ha}$.

Total carbon stock of vegetation in Unnes reached 6.188,57 Mg C scattered in various classes of vegetation density. In the high vegetation density class the total carbon stock is $4.975,14 \mathrm{Mg} \mathrm{C}$, while in the medium class the carbon content is $1.197,86 \mathrm{Mg} \mathrm{C}$. The amount of carbon stock in the low vegetation density class is the smallest than the other vegetation density classes namely by 15,57 ton $\mathrm{C}$.

Tabel 3. Number of Biomass and Carbon Reserves in RTH Unnes In Various Class Cover Land

\begin{tabular}{lcrr}
\hline $\begin{array}{c}\text { Class of } \\
\text { Vegetation }\end{array}$ & $\begin{array}{c}\text { large } \\
\text { (ha) }\end{array}$ & $\begin{array}{r}\text { C-Stok } \\
\text { (ton/ha) }\end{array}$ & \multicolumn{1}{c}{$\begin{array}{c}\text { Total C-Stok } \\
\text { (ton) }\end{array}$} \\
\hline High & 25,49 & 195,18 & $4.975,14$ \\
\hline Medium & 12,81 & 93,51 & $1.197,86$ \\
\hline low & 12,66 & 1,24 & 15,57 \\
\hline Total & 50,96 & 289,92 & $6.188,57$ \\
\hline
\end{tabular}

\subsection{The correlation estimation between NDVI with the Stock Carbon}

Based on result of regression analysis between NDVI with carbon value at field sample location as much as 20 point sample got equation model $\mathrm{Y}=643,8 \mathrm{x}-272,1$. Based on this equation can be known the magnitude of the correlation coefficient (r) is 0.9 while the coefficient of determination (R2) is equal to 0,81 . The value of 0.81 in R2 indicates that NDVI variable can explain $81 \%$ of value of carbon stock, as shown on Fig. 5.

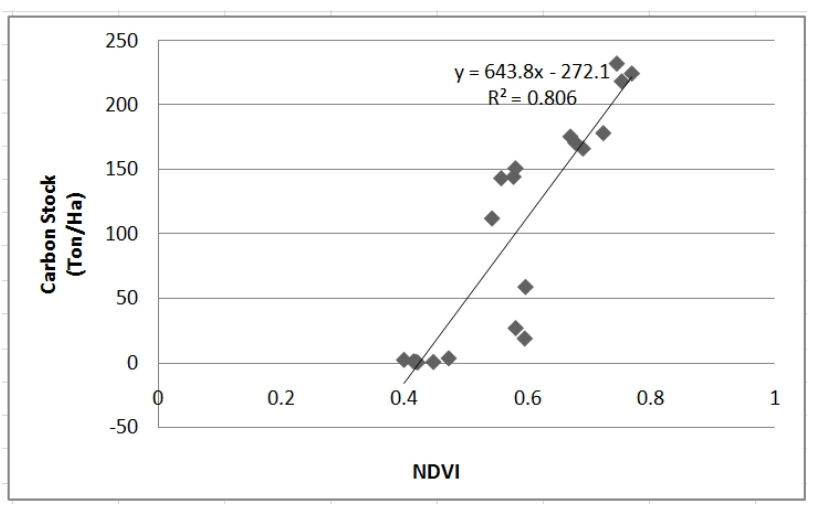

Fig. 5. The relation estimated between NDVI with carbon stocks

\section{Conclusion}

Unnes Sekaran campus has potential of carbon stocks of $6.188,57 \mathrm{Mg}$ or $289,92 \mathrm{Mg} /$ ha. Between carbon stock values Unnes with NDVI values have a correlation coefficient of 0.9 and a coefficient of determination of 0.81 which shows that NDVI variable can explain $81 \%$ value of carbon stock.

\section{References}

1. Unnes Rectors Regulation No. 26 th. 2009 About One Tree Student Planting Movement.

2. University of Indonesia. 2016. UI Green Metric Over All Ranking 2016. On line at http://greenmetric.ui.ac.id/overall-ranking2016/ [accessed on February 10, 2017].

3. Hairiah K, SM. Sitompul, MV. Noordwijk, and C. Palm. 2011. Methods for Sampling Carbon Stocks Above and Below Ground. Bogor: ICRAF

4. [BMKG] Meteorology, Climatology, and Geophysics Council. Information book of climate change and air quality in Indonesia. Jakarta: Meteorology, Climatology, and Geophysics Council; 2012.

5. Lavista, L., L.B. Prasetyo, R. Hermawan. 2016. Dynamics change of the above carbon stocks in Bogor Agricultural University, Darmaga campus. Procedia Environmental Sciences 33 ( 2016 ): HIm $305-316$.

6. Nurmi, 2005. Carbon Sequestration through Management of Plant Residue Conservation and Management (Thesis). Bogor: Bogor Agricultural University.

7. Hairiah K, Rahayu S. 2007. Pengukuran 'karbon tersimpan' di berbagai macam penggunaan lahan. Bogor: World Agroforestry Centre ICRAF, SEA Regional Office, University of Brawijaya, Unibraw, Indonesia. $77 \mathrm{p}$.

8. Watson, Charlene. 2009. Forest Carbon Accounting: Overview \& Principles. London: The United Nations Development Programme.

9. [IPCC] Intergovernmental Panel On Climate Change. 2006. 2006 IPCC Guidelines for National Greenhouse Gas Inventories, Prepared by the National Greenhouse Gas Inventories Programme. Di dalam: Eggleston H.S., Buendia L., Miwa K., Ngara T. and Tanabe K. (eds). Japan: IGES.. Online at http://www.ipcc.ch. [diakses tanggal 09 Agustus 2016].

10. Faizal A, Amran MA. 2005. Model transformasi indeks vegetasi yang efektif untuk prediksi kerapatan mangrove Rhizophora mucronata. Pertemuan Ilmiah Tahunan MAPIN XIV, Pemanfaatan Efektif Penginderaan Jauh untuk Peningkatan Kesejahteraan Bangsa. Surabaya. 
11. Pratiwi, Natalia. 2009. Dampak Spasial Pembangunan Kampus UNNES Terhadap Perubahan Penggunaan Lahan di Kelurahan Sekaran Kecamatan Gunungpati Kota Semarang (Skripsi). Semarang: FIS UNNES.

12. Yuniarto, Nuas. 2013. Dampak Keberadaan Universitas Negeri Semarang Terhadap Harga
Lahan di Kelurahan Sekaran Kecamatan Gunungpati KOTA Semarang

13. Lufilah, SN. 2017. Pemanfaatan Citra Landsat 8 Untuk Analisis Indeks Vegetasi di DKI Jakarta. Jurnal Lanskap Indonesia, 9 (1): 73-80. 